\title{
Ascospore size declines with elevation in two tropical parmelioid lichens
}

\author{
Didier Masson ${ }^{1 *} \&$ Nicolas Magain ${ }^{2}$
}

\section{Article info}

Received: 31 Aug. 2019

Revision received: 9 Mar. 2020

Accepted: 15 Mar. 2020

Published: 2 Jun. 2020

\section{Associate Editor}

Bernard Goffinet

\begin{abstract}
Spore size and shape are biometric parameters frequently used in lichen taxonomy, especially in species characterization. However, the influence of environmental factors on the intraspecific variability of these characters remains very little investigated in lichenology. The elevational variation in spore length, width, volume and shape (length/ width ratio) of two species of the genus Hypotrachyna (H. aff. damaziana et H. altorum) occurring on Réunion Island (Indian Ocean) were studied. Spore length, width and volume significantly decrease with elevation in $H$. aff. damaziana, and spore width and volume also significantly decrease with elevation in H. altorum. There is no relation between spore shape and elevation in either of the two species. A significant correlation was further observed between the intra-individual variability in spore size of $H$. aff. damaziana and elevation. For this species, inter-individual variability in spore volume is also correlated with mean annual temperature and mean annual precipitation of the sampling locations, and spore width and length are correlated with mean annual temperature.
\end{abstract}

Key words: Ascomycota, Parmeliaceae, Hypotrachyna, Réunion Island, spore morphometry, intraspecific variation

\section{Introduction}

Ascospore size provides a relevant diagnostic character frequently used for taxonomic purposes in lichenized fungi, including species delimitation (e.g., Poelt 1973; Löfgren \& Tibell 1979; Clerc 1984; Martínez \& Burgaz 1998; Doré et al. 2006; Argüello et al. 2007; Truong et al. 2009; Núñez-Zapata et al. 2011). However, the influence of environmental factors on spore size within a species remains largely unexplored in lichenology (Hawksworth 1973). In a review on environmental modification and lichen taxonomy, Weber (1977) wrote: 'Differences in ascospores are accorded paramount importance in lichen systematics today, but at the species level one should perhaps be asking what effects the environment might have. Spore size, numbers and perhaps even the extent of septation suggest themselves as characters on which further studies should be carried out, but scant attention has been paid to these aspects in recent years'. Four decades later, the state of affairs remains unchanged.

Hypotrachyna aff. damaziana and $H$. altorum are two fairly common foliose lichens on Réunion (van den Boom et al. 2011; Masson 2012), a rather young tropical volcanic island in the Mascarene Archipelago, with the highest

\footnotetext{
1386 rue des Flamboyants, F-40600 Biscarrosse, France

${ }^{2}$ Evolution and Conservation Biology, InBios Research Center, Institut de Botanique B22, Université de Liège, Chemin de la vallée 4, 4000 Liège, Belgium

* Corresponding author e-mail: di.masson@wanadoo.fr
}

peak in the Indian Ocean (Piton des Neiges, $3070 \mathrm{~m}$ ). These corticolous lichen-forming Ascomycota reproduce sexually, and their thalli generally produce apothecia with simple, hyaline mature spores. Hypotrachyna aff. damaziana is a taxon with a well-defined phenotype on Réunion Island (Masson unpubl. data). It is morphologically and chemically similar to $H$. damaziana from tropical America and Kenya (Hale 1976; Krog \& Swinscow 1979; Eliasaro \& Adler 2000; Flakus et al. 2012; Nash et al. 2016). Molecular data from thirteen specimens from Réunion (Masson \& Sérusiaux unpubl. data) and one Kenyan specimen (Kirika et al. 2019) show that the two populations are most probably conspecific. However, since the type of $H$. damaziana has been collected in Brazil, molecular studies on Neotropical material are needed to determine whether the African and American specimens belong to the same species. Hypotrachyna aff. damaziana thrives on Réunion in five main habitat types (as defined by Strasberg et al. 2005): submontane and montane forests, Pandanus wet thickets, Acacia montane forests and subalpine thickets, in an elevation range from $620 \mathrm{~m}$ to $2375 \mathrm{~m}$ a.s.l. (Masson unpubl. data). Hypotrachyna altorum has a much more restricted elevation range, $1485-1850 \mathrm{~m}$, and is confined to montane and Acacia montane forests (Masson 2012). The combination of regular spore production and wide elevational range makes $H$. aff. damaziana particularly interesting for testing the influence of environmental 
factors on spore size variability, whereas $H$. altorum, with its smaller elevational range but with a rather similar ecology, could provide an interesting model to compare. Elevational gradients are widely used as 'natural' experiments for testing the response of organisms to abiotic influences, although the diversity of environmental factors varying with elevation makes any interpretation rather tricky (Körner 2007).

Experimental studies have shown that ecological conditions, especially temperature and moisture, affect ascospore morphology in non-lichenized fungi (e.g., Williams 1959; Petrie 1994). Further, because of their unique physiology, lichens are highly sensitive to climatic conditions (Kershaw 1985; van Herk et al. 2002; Palmqvist et al. 2008; Gauslaa 2014). The two Hypotrachyna species under consideration thrive mainly on branches of trees or shrubs with loose crowns and rather light foliage, such as Acacia koa [=A. heterophylla, cf. Le Roux et al. (2014)], the main phorophyte for $H$. aff. damaziana (Masson unpubl. data) and the exclusive one for $\mathrm{H}$. altorum (Masson 2012). It is reasonable to assume that in these well-lit, well-ventilated situations, these lichens are exposed to mesoclimatic variation.

The present work tests two assumptions: (i) spore size, and possibly also spore shape, of both Hypotrachyna species change with the elevation of the sampling localities; and (ii) spore size and/or spore shape correlate with climatic variables such as temperature and/or rainfall and/or solar radiation.

\section{Materials and methods}

Specimen sampling and characterization of localities

Fresh specimens of $H$. aff. damaziana and $H$. altorum were collected on Réunion by the first author between 2003 and 2017. They are preserved in the herbarium of the University of Liège (LG) and the first author's private herbarium. Specimens with at least one well-developed and not parasitized apothecium were collected, for $H$. aff. damaziana, in sixty localities distributed in $481 \times 1 \mathrm{~km}$ cells of the UTM grid system. Thirty-two of these cells (two-thirds) were randomly selected for a statistical study. Specimens of $H$. altorum were collected in twenty-two localities distributed in $141 \times 1 \mathrm{~km}$ cells, and all of these cells were included. Of the 46 cells selected for both species (32 for $H$. aff. damaziana, 14 for $H$. altorum), 19 contained more than one locality and/or more than one specimen. In this case, only one specimen from a single locality was randomly drawn for each of these 19 cells. Thus, each of the 46 samples studied consisted of a single specimen taken from a single locality in a $1 \times 1 \mathrm{~km}$ cell of the UTM grid system. This procedure was chosen to avoid too close proximity between the sampling sites and thus to limit spatial autocorrelation. Data on the samples are included in Table 1 and Figure 1. Four collection sites are shared by the target species. All but three of the studied specimens were collected in July and August, during the 'cool' season (Jumaux et al. 2011).

The elevation of the forty-two localities was determined in the field using a hand-held GPS receiver (Garmin eTrex) and subsequently controlled using CartoExploreur 3 (Bayo) software. Climate data (mean annual temperature, mean annual precipitation, annual mean daily global solar radiation) for each locality were determined from the maps available in Jumaux et al. (2011). The averaging period is 1991-2010 for temperature, 1981-2010 for precipitation, and 2001-2010 for global solar radiation.

\section{Spore measurements}

Ascospores in their fully hydrated state were examined with a Zeiss PrimoStar compound light microscope after being freed from the asci in squash preparations of handcut sections of ascomata mounted in tap water. Only non-deformed spores with coloured cytoplasm filling the entire cell were taken into account. For each sample, 30 randomly selected spores from a single well-developed apothecium were measured using an ocular micrometre at $1000 \times$. For one sample ( $H$. aff. damaziana No. 15), spores from ten apothecia were studied to assess variability of spore size and shape within a single thallus. One of these ten apothecia (apothecium 'A'; Fig. 2) was randomly selected for the comparisons among localities. Thus, the measurements obtained from this apothecium characterize sample No. 15 in the rest of the study. Length and width values were recorded to the nearest $0.5 \mu \mathrm{m}$. The length/ width ratio $(\mathrm{Q})$ was used as an indicator of spore shape. The volume of each measured spore was estimated using the equation of an ellipsoid of revolution (Pentecost 1981).
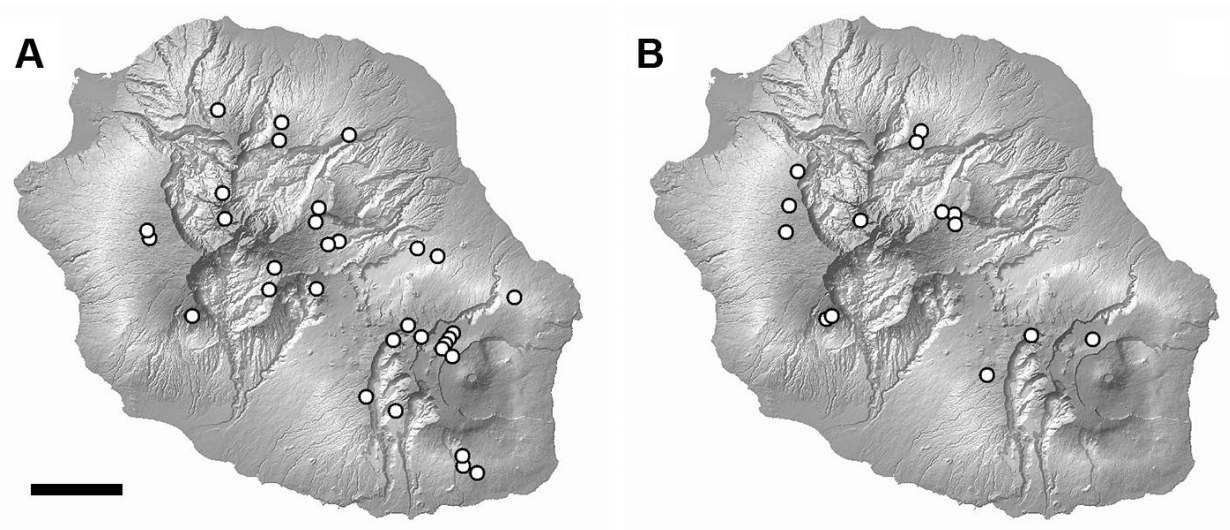

Figure 1. Sampling sites of $H$. aff. damaziana (A) and H. altorum (B) overlain on shade relief maps of Réunion Island. Scale: A, B = $10 \mathrm{~km}$. 
Table 1. Geographical characteristics of the sampling sites, and references of the specimens studied. Samples 1-32 pertain to H. aff. damaziana, samples 33-46 to H. altorum. Collection localities marked ** are shared by both species. Sample numbers in bold type indicate leeward localities; those marked $\S$ indicate specimens whose ITS has been studied.

\begin{tabular}{|c|c|c|c|c|c|c|}
\hline Sample & Locality & Elevation $(\mathrm{m})$ & Latitude $\left(^{\circ}\right)$ & Longitude $\left(^{\circ}\right)$ & Date & Specimen No. \\
\hline 1 & route forestière 38 & 620 & -21.34139 & 55.72041 & 25.08 .2017 & 974.5128 \\
\hline 2 & Sainte-Marguerite & 685 & -21.11583 & 55.67821 & 28.08 .2012 & 974.4106 \\
\hline $3 \S$ & l'Ancienne Nationale & 775 & -21.10970 & 55.65803 & 24.08 .2013 & 974.4434 \\
\hline 4 & forêt de Dioré & 825 & -20.99319 & 55.58195 & 21.08 .2017 & 974.5054 \\
\hline 5 & Rond de Basse Vallée & 840 & -21.33499 & 55.70613 & 16.08 .2013 & 974.4252 \\
\hline $6 \S$ & les Réservoirs & 880 & -21.16026 & 55.75987 & 15.08 .2013 & 974.4234 \\
\hline $7 \S$ & piton Ravine Basse Vallée & 1070 & -21.32497 & 55.70451 & 16.08 .2013 & 974.4284 \\
\hline 8 & Takamaka & 1340 & -21.10227 & 55.56873 & 29072005 & 974.1845 \\
\hline $9 \S$ & ravine des Calumets & 1365 & -21.15008 & 55.49438 & 21.08 .2012 & 974.3937 \\
\hline 10 & plaine des Fougères bas & 1400 & -20.98099 & 55.50752 & 30.08 .2012 & 974.4133 \\
\hline $11 \S$ & les Trois Mares & 1430 & -21.10729 & 55.55827 & 21.08 .2015 & 974.4784 \\
\hline 12 & Bélouve 1 & 1470 & -21.06770 & 55.55180 & 24.08 .2012 & 974.4006 \\
\hline 13 & Grand Coude & 1490 & -21.27520 & 55.63487 & 24.08 .2017 & 974.5120 \\
\hline 14 & Bras Sec & 1505 & -21.12837 & 55.49855 & 22.08 .2012 & 974.3966 \\
\hline 15 & la Roche Écrite & 1515 & -20.96903 & 55.44046 & 20.08 .2015 & 974.4755 \\
\hline 16 & plateau de la Sale & 1520 & -21.04753 & 55.44517 & 24.07 .2005 & 974.1721 \\
\hline 17 & sentier des Tamarins 1 & 1550 & -21.08315 & 55.54543 & 19.07.2005 & 974.1528 \\
\hline 18 & le Mapou & 1580 & -21.20357 & 55.62968 & 24.08 .2015 & 974.4850 \\
\hline $19 \S$ & plaine des Fougères haut** & 1640 & -20.99986 & 55.50687 & 31.08 .2012 & 974.4155 \\
\hline 20 & sommière la Saline & 1710 & -21.09057 & 55.35897 & 10.04 .2003 & 974.0266 \\
\hline 21 & Notre-Dame de la Paix & 1720 & -21.26407 & 55.60259 & 17.07 .2005 & 974.1393 \\
\hline 22 & sommière Éperon** & 1735 & -21.08548 & 55.36013 & 10.04 .2003 & 974.0280 \\
\hline $23 \S$ & piton Tortue & 1735 & -21.15109 & 55.54555 & 23.08 .2013 & 974.4413 \\
\hline 24 & plaine des Tamarins** & 1760 & -21.07904 & 55.44359 & 27.07 .2005 & 974.1762 \\
\hline $25 \S$ & piton de Coco & 1780 & -21.20120 & 55.69633 & 25.08 .2012 & 974.4035 \\
\hline 26 & plateau Goyaves** & 1790 & -21.17989 & 55.40876 & 19.08 .2013 & 974.4321 \\
\hline 27 & fond de la Rivière de l'Est & 1810 & -21.20684 & 55.69185 & 20.07 .2005 & 974.1596 \\
\hline 28 & Rampe Liot 2 & 1915 & -21.21008 & 55.68537 & 20.07 .2005 & 974.1590 \\
\hline 29 & Rampe Liot 1 & 2030 & -21.21347 & 55.68500 & 20.07 .2005 & 974.1604 \\
\hline $30 \S$ & bois Ozoux & 2160 & -21.19227 & 55.64745 & 22.08 .2013 & 974.4394 \\
\hline $31 \S$ & Pas de Bellecombe & 2300 & -21.22057 & 55.69313 & 22.08 .2013 & 974.4374 \\
\hline 32 & rempart de la Rivière de l'Est & 2375 & -21.20383 & 55.65950 & 22.08 .2015 & 974.4797 \\
\hline 33 & Grand Bras Sec & 1485 & -20.98934 & 55.51027 & 31.08 .2012 & 974.4161 \\
\hline 34 & plateau Citron & 1535 & -21.07409 & 55.54726 & 24.08 .2012 & 974.3998 \\
\hline 35 & sentier des Tamarins 2 & 1550 & -21.08410 & 55.54571 & 19.07.2005 & 974.1538 \\
\hline 36 & rivière d'Abord & 1570 & -21.23994 & 55.58475 & 23.07 .2005 & 974.1678 \\
\hline 37 & sentier Oméga & 1600 & -21.02712 & 55.37857 & 31.07 .2005 & 974.1877 \\
\hline $38 \S$ & plaine des Fougères haut** & 1640 & -20.99986 & 55.50687 & 31.08 .2012 & 974.4152 \\
\hline $39 \S$ & Bélouve 2 & 1650 & -21.07385 & 55.53042 & 25.08 .2013 & 974.4488 \\
\hline 40 & sommière Éperon** & 1735 & -21.08548 & 55.36013 & 10.04 .2003 & 974.0272 \\
\hline 41 & plaine des Tamarins** & 1760 & -21.07904 & 55.44359 & 27.07 .2005 & 974.1763 \\
\hline $42 \S$ & ravine Savane & 1775 & -21.20372 & 55.69615 & 25.08 .2012 & 974.4039 \\
\hline 43 & plateau Goyaves** & 1790 & -21.17989 & 55.40876 & 19.08 .2013 & 974.4320 \\
\hline 44 & Dennemont & 1790 & -21.06087 & 55.36983 & 02.08 .2005 & 974.1906 \\
\hline 45 & le Petit Mapou & 1805 & -21.19830 & 55.63255 & 24.08 .2015 & 974.4842 \\
\hline $46 \S$ & Haut des Makes & 1850 & -21.17676 & 55.41276 & 19.08 .2013 & 974.4323 \\
\hline
\end{tabular}

The arithmetic mean spore length, width, Q and volume, their standard deviation and coefficient of variation (incl. Haldane correction; Haldane 1955) were calculated for each sample. Considering that the variation of spores between the different individuals of a species (intraspecific variation) is a trait of the species, whereas the spore variation within one individual (intra-individual variation) is only the attribute of that individual (Raitviir 1972; Parmasto \& Parmasto 1987), statistics for the overall spore measurements of each of the two species studied are presented in the format: $(\mathrm{M}-\mathrm{SD})-M-(\mathrm{M}+\mathrm{SD})$, where $\mathrm{M}$ is the arithmetical mean of the mean values of the samples (in italics) and SD its standard deviation.

\section{Statistical analyses}

Statistical analyses were performed using R (R Core Team 2018) and R packages 'car' (Fox et al. 2012), 'dplyr' (Wickham et al. 2016), 'ggpubr' (Kassambara 2017) and 'reshape2' (Wickham 2012). The normality distribution of variables was checked using quantile-quantile (Q-Q) plots 


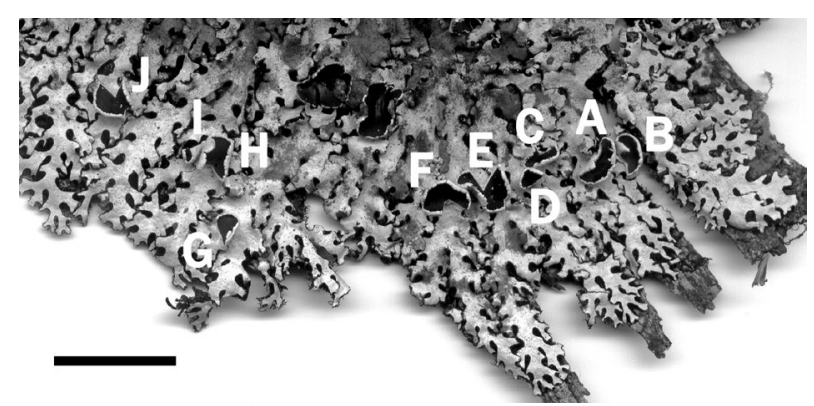

Figure 2. The ten apothecia investigated in sample No. 15 (Hypotrachyna aff. damaziana, specimen No. 974.4755). Scale bar $=1 \mathrm{~cm}$.

and the Shapiro-Wilk test. Homogeneity of variance was investigated using Levene's test and by plotting residuals vs. fits. To verify whether, for each of the two species, the set of samples represents a single homogeneous population, we used the Hartigans' dip test for unimodality. One-way analysis of variance was chosen to compare the means of the spore variables between groups when the variances were homogeneous; otherwise Welch's oneway ANOVA was used. The relationships between spore traits and elevation, spore traits and climatic variables, spore traits and apothecia diameter, and between climatic variables were determined with two-tailed Spearman rank correlation tests. When analysing associations between spore traits and climatic variables, the family-wise error rate was reduced by using the sequential Bonferroni procedure (Holm 1979; Rice 1989). When significant correlations were found, multiple linear regressions were performed. Adequacy of the regressions was assessed using the gvlma (Global Validation of Linear Models Assumptions) function of the gvlma $\mathrm{R}$ package (Pena $\&$ Slate 2012). Comparison of fitted models was performed with ANOVA tables using the Anova function.

\section{Results}

Variation of the climatic parameters of the sampling localities

Unsurprisingly, the mean annual temperature of a locality strongly depends on its elevation (Spearman rank correlation, $\mathrm{r}_{\mathrm{s}}=-0.8201, P=3.0 \times 10^{-11}$, two-tailed).
However, there is no significant relationship between mean annual rainfall and elevation $\left(\mathrm{r}_{\mathrm{s}}=-0.1182, P=0.46\right.$, two-tailed), nor between mean annual rainfall and mean annual temperature at each locality $\left(\mathrm{r}_{\mathrm{s}}=-0.0343, P=0.83\right.$, two-tailed). The lack of correlation between rainfall and elevation could be partly related to local exposure to trade winds. The fourteen leeward localities sampled are distributed between $1365 \mathrm{~m}$ and $1850 \mathrm{~m}$ a.s.1., while fifteen windward localities are in the same elevational range (Table 1). Comparison of the mean annual precipitation of these twenty-nine locations depending on their wind exposure (Student's t-test, $\mathrm{t}=4.146, \mathrm{df}=27, P=1.5 \times 10^{-4}$, one-tailed) confirms that rainfall tends to be greater in windward situations (mean value $4060 \mathrm{~mm}$ ) than in leeward situations (mean value $2479 \mathrm{~mm}$ ).

Annual mean daily global solar radiation of the forty-two localities is significantly correlated with elevation $\left(\mathrm{r}_{\mathrm{s}}=0.3228, P=0.037\right.$, two-tailed), mean annual temperature $\left(\mathrm{r}_{\mathrm{s}}=-0.3893, P=0.011\right.$, two-tailed $)$ and mean annual rainfall $\left(\mathrm{r}_{\mathrm{s}}=0.6087, P=1.9 \times 10^{-5}\right.$, two-tailed).

\section{Within-thallus spore variation in Hypotrachyna aff. damaziana}

Levene's test does not support heterogeneity of variance for any of the four parameters tested (length, width, volume and Q ratio) between ten different apothecia of the same thallus (sample No. 15; Table 2). Q-Q plots suggest normality of the data, even if Shapiro-Wilk tests are significant for lengths, widths and volumes. The mean lengths of spores do not significantly differ between the ten apothecia (one-way ANOVA, $\mathrm{F}_{9,290}=1.185, P=0.30$ ); the same is true for widths $\left(\mathrm{F}_{9,290}=0.425, P=0.92\right)$, volumes $\left(\mathrm{F}_{9,290}=0.295, P=0.98\right)$ and $\mathrm{Q}$ values $\left(\mathrm{F}_{9,290}=1.342\right.$, $P=0.21)$. Moreover, the coefficients of variation of the mean values of the samples are low and range between $1.1 \%$ and $2.2 \%$ for the four parameters studied $(1.1 \%$ for width, $1.4 \%$ for length, $2.2 \%$ for volume and $\mathrm{Q}$ value).

\section{Spore variation and size of apothecia}

The sampled apothecia vary in size, and therefore in age. The diameter of the hymenial disc varies from 1.2 to $6.4 \mathrm{~mm}$ (mean: $3.15 \mathrm{~mm}$ ) for the samples of $H$. aff. damaziana, and from 1.5 to $4.1 \mathrm{~mm}$ (mean: $2.50 \mathrm{~mm}$ ) for

Table 2. Variation of mean spore measurements, Q values and their standard deviation (SD) in ten apothecia of the same $H$. aff. damaziana thallus (sample No. 15, specimen No. 974.4755). Thirty spores were measured in each apothecium.

\begin{tabular}{c|cc|cc|cc|cc}
\hline \multirow{2}{*}{ Apothecia } & \multicolumn{2}{|c|}{ Spore width } & \multicolumn{2}{c|}{ Spore length } & \multicolumn{2}{c|}{ Spore volume } & \multicolumn{2}{c}{ Q } \\
\cline { 2 - 9 } & $\begin{array}{c}\text { mean } \\
(\mu \mathrm{m})\end{array}$ & $\begin{array}{c}\text { SD } \\
(\mu \mathrm{m})\end{array}$ & $\begin{array}{c}\text { mean } \\
(\mu \mathrm{m})\end{array}$ & $\begin{array}{c}\text { SD } \\
(\mu \mathrm{m})\end{array}$ & $\begin{array}{c}\text { mean } \\
\left(\mu \mathrm{m}^{3}\right)\end{array}$ & $\begin{array}{c}\text { SD } \\
\left(\mu \mathrm{m}^{3}\right)\end{array}$ & mean & SD \\
\hline A & 9.05 & 0.747 & 13.55 & 0.792 & 586.4 & 108.97 & 1.51 & 0.134 \\
B & 9.10 & 0.792 & 12.93 & 1.073 & 564.1 & 104.70 & 1.43 & 0.187 \\
C & 9.02 & 1.038 & 13.45 & 0.922 & 584.1 & 157.64 & 1.51 & 0.154 \\
D & 8.95 & 0.844 & 13.27 & 0.878 & 562.4 & 113.62 & 1.49 & 0.152 \\
E & 9.25 & 0.828 & 13.28 & 1.104 & 602.4 & 130.81 & 1.44 & 0.152 \\
F & 9.10 & 0.759 & 13.27 & 0.598 & 580.2 & 104.05 & 1.47 & 0.127 \\
G & 9.18 & 0.951 & 13.08 & 0.929 & 587.8 & 142.57 & 1.43 & 0.130 \\
H & 9.10 & 0.845 & 13.32 & 0.886 & 583.8 & 117.62 & 1.47 & 0.154 \\
I & 9.03 & 0.860 & 13.37 & 1.017 & 580.5 & 132.96 & 1.49 & 0.129 \\
J & 9.27 & 0.848 & 13.10 & 0.865 & 595.6 & 119.66 & 1.42 & 0.143 \\
\hline
\end{tabular}


those of $H$. altorum. For the 32 samples of $H$. aff. damaziana, mean spore width correlates significantly with the diameter of the hymenial disc (Spearman rank correlation, $\mathrm{r}_{\mathrm{s}}=0.5201, P=0.0023$, two-tailed); so does mean spore volume $\left(\mathrm{r}_{\mathrm{s}}=0.4915, P=0.0043\right.$, two-tailed). There is no significant relationship between mean length and disc diameter ( $\mathrm{r}_{\mathrm{s}}=0.2300, P=0.21$, two-tailed), nor between $\mathrm{Q}$ and disc diameter $\left(\mathrm{r}_{\mathrm{s}}=-0.2384, P=0.19\right.$, two-tailed $)$ in this species. Regarding the 14 samples of H. altorum, the mean length and mean volume of the spores are significantly correlated with the diameter of the hymenial disc (length: $\mathrm{r}_{\mathrm{s}}=-0.6042, P=0.0221$, two-tailed; volume: $\mathrm{r}_{\mathrm{s}}=-0.5954, P=0.0247$, two-tailed). However, there is no significant correlation between disc diameter and mean width $\left(\mathrm{r}_{\mathrm{s}}=-0.4294, P=0.13\right.$, two-tailed) or $\mathrm{Q}$ ratio $\left(\mathrm{r}_{\mathrm{s}}=-0.1115, P=0.70\right.$, two-tailed). No significant relationship was found between the elevation of localities and the diameter of the hymenial disc in samples of $H$. aff. damaziana $\left(\mathrm{r}_{\mathrm{s}}=-0.2380, P=0.19\right.$, two-tailed $)$ or $H$. altorum $\left(\mathrm{r}_{\mathrm{s}}=0.2594, P=0.37\right.$, two-tailed $)$.

Spore variation among localities in Hypotrachyna aff. damaziana

The overall dimensions of the ascospores measured from the 32 specimens are as follows: length 12.8$13.51-14.2 \mu \mathrm{m}$, width 8.8-9.25-9.7 $\mu \mathrm{m}$, volume 532.1614.20-696.3 $\mu^{3}$ and Q 1.40-1.47-1.55. Detailed statistical parameters for each sample are presented in Table 3. It appears that spore size and spore shape vary appreciably from one sample to another. Welch's one-way analysis of variance of the data on spore size and spore shape shows that there is a very significant difference across mean length $\left(\mathrm{F}_{31,329.26}=20.519, P=2.5 \times 10^{-59}\right)$, width $\left(\mathrm{F}_{31,329.25}=10.664, P=7.7 \times 10^{-34}\right)$, volume $\left(\mathrm{F}_{31,329.21}=15.043, P=3.1 \times 10^{-46}\right)$ and $\mathrm{Q}\left(\mathrm{F}_{31,329.25}=8.725\right.$, $P=1.2 \times 10^{-27}$ ) among the 32 samples. However, the results of the Hartigans' dip test on the data used show that there is no reason to consider the study population as heterogeneous, either for length $(P=0.58)$, width $(P=0.97)$, volume $(P=0.62)$ or $\mathrm{Q}$ values $(P=0.97)$. Furthermore, the comparison between the mean value of the coefficients of variation of the samples and the coefficient of variation for the mean values of the samples shows that the former ('intrathalline variation', or more exactly 'intra-apothecial variation') is greater than the latter ('interthalline variation') for each of the parameters studied (Table 4).

The average spore size of specimens varies with elevation. The mean values of width, length and volume correlate significantly with the elevation of the sampling localities: the three variables decrease as the elevation increases (Table 5). The best correlation was found with average volume (Fig. 3). The coefficients of variation (CV) for the three size parameters are also significantly correlated with elevation (Table 5). This suggests that intrathalline variability in spore size changes with elevation. The CV of length increases with elevation, while the $\mathrm{CV}$ of width and volume decreases. Unlike spore size variables, there is no significant relationship between the mean $\mathrm{Q}$ value, or the $\mathrm{CV}$ of $\mathrm{Q}$ values,

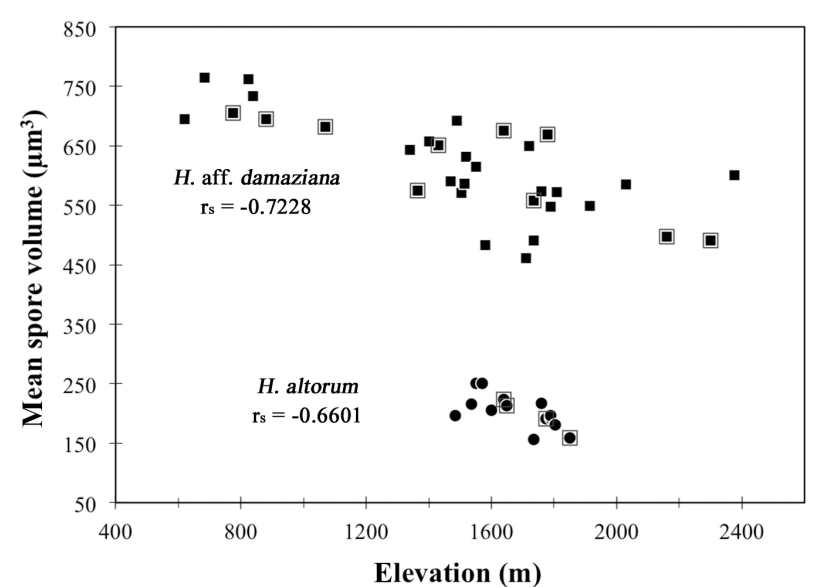

Figure 3. Scatter plot of mean spore volume versus elevation for $H$. aff. damaziana and H. altorum, and Spearman's rank correlation coefficients. Points within boxes are samples whose ITS has been studied.

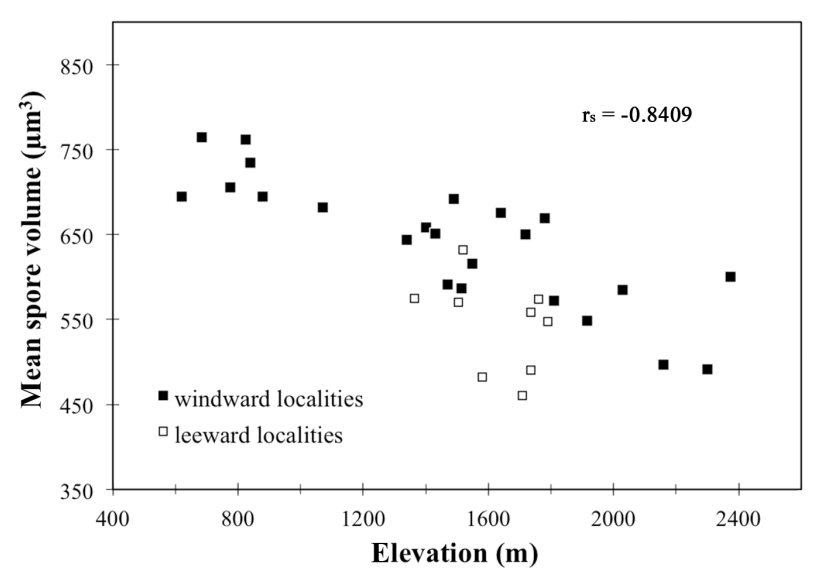

Figure 4. Scatter plot of mean spore volume versus elevation for samples of $H$. aff. damaziana, with windward localities separated from leeward localities. Spearman's rank correlation coefficient for windward localities only.

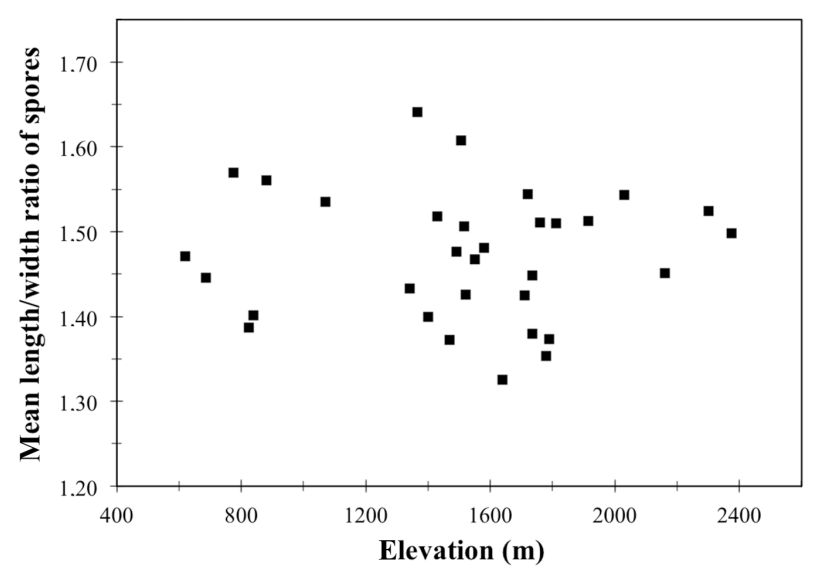

Figure 5. Scatter plot showing the absence of relation (Spearman's rank correlation, $r_{\mathrm{s}}=-0.0187$ ) between mean spore length/width ratio (Q) and elevation among samples of $H$. aff. damaziana.

and elevation (Table 5, Fig. 5). While mean spore size decreases clearly with elevation, the shape of the spores does not change.

Among the three climatic parameters selected as variables likely to be linked to interthalline variation in spore size or shape, mean annual temperature of sampling 
Table 3. Variation of mean spore measurements, Q values and their standard deviation (SD) in the 32 samples of H. aff. damaziana (samples 1-32) and the 14 samples of H. altorum (samples 33-46). Thirty spores were measured in each sample. Extreme values for each species are underlined for each parameter.

\begin{tabular}{|c|c|c|c|c|c|c|c|c|}
\hline \multirow[b]{2}{*}{ Sample } & \multicolumn{2}{|c|}{ Spore width } & \multicolumn{2}{|c|}{ Spore length } & \multicolumn{2}{|c|}{ Spore volume } & \multicolumn{2}{|c|}{ Q } \\
\hline & $\begin{array}{c}\text { mean } \\
(\mu \mathrm{m})\end{array}$ & $\begin{array}{c}\text { SD } \\
(\mu \mathrm{m})\end{array}$ & $\begin{array}{l}\text { mean } \\
(\mu \mathrm{m})\end{array}$ & $\begin{array}{c}\text { SD } \\
(\mu \mathrm{m})\end{array}$ & $\begin{array}{l}\text { mean } \\
\left(\mu \mathrm{m}^{3}\right)\end{array}$ & $\begin{array}{c}\mathrm{SD} \\
\left(\mu \mathrm{m}^{3}\right)\end{array}$ & mean & SD \\
\hline 1 & 9.63 & 1.121 & 14.03 & 0.870 & 694.7 & 186.52 & 1.47 & 0.156 \\
\hline 2 & 10.00 & 1.114 & 14.32 & 1.118 & $\underline{764.2}$ & $\underline{194.83}$ & 1.45 & 0.165 \\
\hline 3 & 9.52 & 1.054 & $\underline{14.73}$ & 0.817 & 705.6 & 153.31 & 1.57 & $\underline{0.222}$ \\
\hline 4 & $\underline{10.13}$ & 0.982 & 13.97 & 1.074 & 761.6 & 171.56 & 1.39 & 0.142 \\
\hline 5 & 9.98 & 0.782 & 13.93 & 0.763 & 734.0 & 131.76 & 1.40 & 0.107 \\
\hline 6 & 9.47 & 0.718 & 14.70 & 0.887 & 695.0 & 120.00 & 1.56 & 0.137 \\
\hline 7 & 9.48 & 0.866 & 14.42 & 0.810 & 682.1 & 118.06 & 1.54 & 0.190 \\
\hline 8 & 9.48 & 0.748 & 13.53 & 0.809 & 643.6 & 119.94 & 1.43 & 0.113 \\
\hline 9 & 8.73 & 0.917 & 14.18 & 0.713 & 574.6 & 131.23 & $\underline{1.64}$ & 0.172 \\
\hline 10 & 9.63 & 0.840 & 13.40 & 0.865 & 657.9 & 133.64 & 1.40 & 0.139 \\
\hline 11 & 9.35 & 0.709 & 14.12 & 0.806 & 651.1 & 109.84 & 1.52 & 0.130 \\
\hline 12 & 9.35 & 0.789 & 12.77 & 0.785 & 590.8 & 112.78 & 1.37 & 0.115 \\
\hline 13 & 9.62 & 0.862 & 14.08 & 0.980 & 692.1 & 165.23 & 1.48 & 0.146 \\
\hline 14 & 8.77 & 0.740 & 14.02 & 0.924 & 570.4 & 117.25 & 1.61 & 0.131 \\
\hline 15 & 9.05 & 0.747 & 13.55 & 0.792 & 586.4 & 108.97 & 1.51 & 0.134 \\
\hline 16 & 9.47 & 0.776 & 13.40 & 0.968 & 631.5 & 106.33 & 1.43 & 0.175 \\
\hline 17 & 9.28 & 0.773 & 13.53 & 1.066 & 615.3 & 112.81 & 1.47 & 0.161 \\
\hline 18 & 8.53 & 0.601 & 12.58 & 0.920 & 482.7 & 80.37 & 1.48 & 0.145 \\
\hline 19 & 9.88 & 0.897 & 13.03 & 0.798 & 675.2 & 144.81 & 1.33 & 0.109 \\
\hline 20 & 8.52 & 0.650 & $\underline{12.07}$ & $\underline{0.691}$ & $\underline{460.7}$ & $\underline{75.14}$ & $\overline{1.43}$ & 0.137 \\
\hline 21 & 9.28 & 0.727 & $\overline{14.27}$ & $\overline{1.096}$ & $\overline{650.1}$ & $\overline{132.53}$ & 1.54 & 0.145 \\
\hline 22 & 8.63 & $\underline{0.556}$ & 12.48 & 0.725 & 490.3 & 77.91 & 1.45 & $\underline{0.106}$ \\
\hline 23 & 9.17 & $\overline{0.834}$ & 12.57 & 0.828 & 558.4 & 113.20 & 1.38 & $\overline{0.142}$ \\
\hline 24 & 8.99 & 0.688 & 13.51 & 0.900 & 574.0 & 97.74 & 1.51 & 0.151 \\
\hline 25 & 9.80 & 0.610 & 13.23 & 0.944 & 669.3 & 107.86 & 1.35 & 0.111 \\
\hline 26 & 9.13 & 0.798 & 12.45 & 0.824 & 548.0 & 105.38 & 1.37 & 0.155 \\
\hline 27 & 8.97 & 0.565 & 13.49 & 0.871 & 572.1 & 75.34 & 1.51 & 0.147 \\
\hline 28 & 8.85 & 0.645 & 13.32 & 0.914 & 548.9 & 86.97 & 1.51 & 0.154 \\
\hline 29 & 8.97 & 0.681 & 13.78 & 1.430 & 585.0 & 111.39 & 1.54 & 0.173 \\
\hline 30 & 8.67 & 0.634 & 12.53 & $\overline{0.991}$ & 497.0 & 94.10 & 1.45 & 0.134 \\
\hline 31 & $\underline{8.48}$ & 0.663 & 12.88 & 0.926 & 491.1 & 101.11 & 1.52 & 0.111 \\
\hline 32 & $\overline{9.15}$ & 0.789 & 13.60 & 1.170 & 600.5 & 115.71 & 1.50 & 0.196 \\
\hline 33 & 6.53 & $\underline{0.571}$ & 8.70 & 0.783 & 196.7 & 41.20 & 1.34 & 0.148 \\
\hline 34 & 6.78 & $\overline{0.503}$ & 8.87 & 0.615 & 215.6 & 40.25 & 1.31 & $\underline{0.107}$ \\
\hline 35 & $\underline{7.15}$ & 0.476 & 9.32 & 0.663 & 250.8 & 40.23 & 1.31 & $\overline{0.124}$ \\
\hline 36 & 6.98 & 0.500 & $\underline{9.77}$ & 0.785 & $\underline{251.1}$ & $\underline{43.99}$ & 1.41 & 0.143 \\
\hline 37 & 6.68 & $\underline{0.334}$ & $\overline{8.77}$ & 0.666 & $\overline{205.1}$ & $\overline{22.28}$ & 1.32 & 0.137 \\
\hline 38 & 6.88 & $\overline{0.520}$ & 8.92 & 0.720 & 223.5 & 43.26 & 1.30 & 0.116 \\
\hline 39 & 6.53 & 0.414 & 9.55 & 0.758 & 213.3 & 24.64 & 1.47 & $\underline{0.174}$ \\
\hline 40 & $\underline{5.82}$ & 0.464 & 8.73 & 0.626 & $\underline{156.3}$ & 28.68 & $\underline{1.50}$ & $\overline{0.125}$ \\
\hline 41 & $\overline{6.70}$ & 0.484 & 9.17 & 0.711 & $\overline{217.0}$ & 38.47 & $\overline{1.38}$ & 0.135 \\
\hline 42 & 6.58 & 0.417 & 8.40 & 0.770 & 191.1 & 27.86 & 1.28 & 0.156 \\
\hline 43 & 6.37 & 0.556 & 8.98 & 0.688 & 192.9 & 41.25 & $\overline{1.42}$ & 0.139 \\
\hline 44 & 6.62 & 0.387 & 8.50 & $\underline{0.881}$ & 195.8 & 32.12 & 1.29 & 0.140 \\
\hline 45 & 6.15 & 0.494 & 9.07 & $\overline{0.568}$ & 181.2 & 33.23 & 1.48 & 0.135 \\
\hline 46 & 6.10 & 0.481 & $\underline{8.08}$ & $\overline{0.588}$ & 158.3 & 25.73 & 1.33 & 0.148 \\
\hline
\end{tabular}

localities is positively and significantly correlated with mean spore length, width and volume, but not with mean $Q$ value (Table 5). There is no significant relationship between spore size or shape parameters and mean annual precipitation, except for mean spore volume, which increases with annual rainfall. No correlation between annual mean daily global solar radiation and the size or shape of spores was found.
We tested multiple linear regressions with elevation, mean annual temperature, mean precipitation, as well as diameter of apothecia disc as explanatory variables for the variation in spore width, length and volume. For all multiple linear regressions, ANOVA tests never selected a model including both elevation and mean annual temperature. This can be linked to the high correlation of these two values (see above). For spore width, a model 
Table 4. Intra- and interthalline variation of spore measurements and Q values estimated from the coefficients of variation (CV) of the samples for each of the two species $H$. aff. damaziana (in bold) and $H$. altorum (in italics). All values are in percentages. A two-tailed Student's t-test was performed to compare the mean values of the CV of the samples between the two taxa (**: $P<0.01, *: P<0.05$, NS: not significant).

\begin{tabular}{lcccc|c}
\hline & \multicolumn{3}{c|}{ Intrathalline variation } & Interthalline variation \\
\cline { 2 - 6 } & $\begin{array}{c}\text { min. value of CV } \\
\text { of samples }\end{array}$ & $\begin{array}{c}\text { max. value of CV } \\
\text { of samples }\end{array}$ & $\begin{array}{c}\text { mean value of CV } \\
\text { of samples }\end{array}$ & $\begin{array}{c}\text { CV of mean values } \\
\text { of samples }\end{array}$ \\
\hline Spore width & $\mathbf{6 . 3}$ & $\mathbf{1 1 . 7}$ & $\mathbf{8 . 5}$ & $* *$ & $\mathbf{5 . 0}$ \\
& 5.0 & 8.8 & 7.3 & & 5.6 \\
Spore length & $\mathbf{5 . 1}$ & $\mathbf{1 0 . 5}$ & $\mathbf{6 . 8}$ & $* *$ & $\mathbf{5 . 3}$ \\
& 6.3 & 10.5 & 7.9 & & 5.1 \\
Spore volume & $\mathbf{1 3 . 3}$ & $\mathbf{2 7 . 1}$ & $\mathbf{1 9 . 4}$ & $*$ & $\mathbf{1 3 . 5}$ \\
& 11.0 & 21.6 & 17.1 & & 14.2 \\
Q & $\mathbf{7 . 4}$ & $\mathbf{1 4 . 3}$ & $\mathbf{1 0 . 0}$ & NS & $\mathbf{5 . 2}$ \\
& 8.3 & 12.2 & 10.2 & 5.7 \\
\hline
\end{tabular}

Table 5. Results of two-tailed Spearman's rank correlation between $H$. aff. damaziana spore traits and selected environmental factors. Correlation coefficients in bold type are statistically significant at $P<0.05$ (significance levels adjusted with the sequential Bonferroni correction for tests involving climate parameters). $\mathrm{CV}$ : coefficient of variation.

\begin{tabular}{|c|c|c|c|c|}
\hline & Elevation & $\begin{array}{c}\text { Mean annual } \\
\text { temperature }\end{array}$ & $\begin{array}{l}\text { Mean annual } \\
\text { precipitation }\end{array}$ & $\begin{array}{l}\text { Annual mean daily } \\
\text { global solar radiation }\end{array}$ \\
\hline Mean width & $\begin{array}{l}\mathbf{r}_{\mathbf{s}}=-\mathbf{0 . 6 4 1 3} \\
P=7.7 \times 10^{-5}\end{array}$ & $\begin{array}{c}\mathbf{r}_{\mathbf{s}}=\mathbf{0 . 6 9 8 1} \\
P=8.9 \times 10^{-6}\end{array}$ & $\begin{array}{c}\mathrm{r}_{\mathrm{s}}=0.3186 \\
P=0.076\end{array}$ & $\begin{array}{c}\mathrm{r}_{\mathrm{s}}=-0.3455 \\
P=0.053\end{array}$ \\
\hline $\mathrm{CV}$ of width & $\begin{array}{l}\mathbf{r}_{\mathbf{s}}=-\mathbf{0 . 5 6 5 3} \\
P=7.5 \times 10^{-4}\end{array}$ & $\begin{array}{c}\mathbf{r}_{\mathbf{s}}=\mathbf{0 . 6 8 2 9} \\
P=1.7 \times 10^{-5}\end{array}$ & $\begin{array}{c}\mathrm{r}_{\mathrm{s}}=-0.1696 \\
P=0.35\end{array}$ & $\begin{array}{c}\mathrm{r}_{\mathrm{s}}=-0.3864 \\
P=0.029\end{array}$ \\
\hline Mean length & $\begin{array}{c}\mathbf{r}_{\mathbf{s}}=-\mathbf{0 . 6 2 6 8} \\
P=1.2 \times 10^{-4}\end{array}$ & $\begin{array}{c}\mathbf{r}_{\mathbf{s}}=\mathbf{0 . 5 5 8 7} \\
P=8.9 \times 10^{-4}\end{array}$ & $\begin{array}{l}\mathrm{r}_{\mathrm{s}}=0.3407 \\
P=0.056\end{array}$ & $\begin{array}{c}\mathrm{r}_{\mathrm{s}}=0.0134 \\
P=0.94\end{array}$ \\
\hline $\mathrm{CV}$ of length & $\begin{array}{l}\mathbf{r}_{\mathrm{s}}=\mathbf{0 . 4 9 5 3} \\
P=0.0039\end{array}$ & $\begin{array}{c}\mathbf{r}_{\mathbf{s}}=-\mathbf{0 . 4 2 8 4} \\
P=0.014\end{array}$ & $\begin{array}{c}\mathrm{r}_{\mathrm{s}}=0.1109 \\
P=0.55\end{array}$ & $\begin{array}{c}\mathrm{r}_{\mathrm{s}}=0.3625 \\
P=0.042\end{array}$ \\
\hline Mean volume & $\begin{array}{l}\mathbf{r}_{\mathbf{s}}=-\mathbf{0 . 7 2 2 8} \\
P=3.0 \times 10^{-6}\end{array}$ & $\begin{array}{c}\mathbf{r}_{\mathbf{s}}=\mathbf{0 . 7 2 1 9} \\
P=3.1 \times 10^{-6}\end{array}$ & $\begin{array}{c}\mathbf{r}_{\mathbf{s}}=\mathbf{0 . 4 0 2 0} \\
P=0.023\end{array}$ & $\begin{array}{c}\mathrm{r}_{\mathrm{s}}=-0.2610 \\
P=0.15\end{array}$ \\
\hline $\mathrm{CV}$ of volume & $\begin{array}{c}\mathbf{r}_{\mathbf{s}}=-\mathbf{0 . 3 8 4 2} \\
P=0.030\end{array}$ & $\begin{array}{l}\mathbf{r}_{\mathbf{s}}=\mathbf{0 . 5 2 0 3} \\
P=0.0023\end{array}$ & $\begin{array}{c}\mathrm{r}_{\mathrm{s}}=-0.1005 \\
P=0.58\end{array}$ & $\begin{array}{c}\mathrm{r}_{\mathrm{s}}=-0.1861 \\
P=0.31\end{array}$ \\
\hline Mean Q & $\begin{array}{c}\mathrm{r}_{\mathrm{s}}=-0.0187 \\
P=0.92\end{array}$ & $\begin{array}{c}\mathrm{r}_{\mathrm{s}}=-0.0736 \\
P=0.69\end{array}$ & $\begin{array}{c}\mathrm{r}_{\mathrm{s}}=0.1504 \\
P=0.41\end{array}$ & $\begin{array}{c}\mathrm{r}_{\mathrm{s}}=0.3875 \\
P=0.029\end{array}$ \\
\hline CV of Q & $\begin{array}{c}\mathrm{r}_{\mathrm{s}}=-0.1041 \\
P=0.57\end{array}$ & $\begin{array}{c}\mathrm{r}_{\mathrm{s}}=0.1294 \\
P=0.48\end{array}$ & $\begin{array}{c}\mathrm{r}_{\mathrm{s}}=0.0176 \\
P=0.92\end{array}$ & $\begin{array}{c}\mathrm{r}_{\mathrm{s}}=-0.0269 \\
P=0.88\end{array}$ \\
\hline
\end{tabular}

with mean annual temperature and apothecia size as the explanatory variables was selected. A significant regression equation was found $\left[\mathrm{F}_{2,29}=17.83, P=8.9 \times 10^{-6}\right.$, with an R-squared of 0.5206]. Spore's predicted width (in $\mu \mathrm{m}$ ) is equal to $7.313+0.10 *$ mean temperature (in ${ }^{\circ} \mathrm{C}$ ) + $0.12 *$ disc diameter (in $\mathrm{mm}$ ). For spore length, a model with mean annual precipitation and elevation was selected. A significant regression equation was found $\left[\mathrm{F}_{2,29}=12.13\right.$, $P=1.5 \times 10^{-4}$, with an R-squared of 0.418$]$. Spore's predicted length (in $\mu \mathrm{m}$ ) is equal to $14.248+0.00123 *$ mean precipitation (in $\mathrm{mm}$ ) $-0.000819 *$ elevation (in $\mathrm{m}$ ). For volume, a model with mean annual temperature and mean annual precipitation was selected. A significant regression equation was found $\left[\mathrm{F}_{2,29}=26.48, P=2.9 \times 10^{-7}\right.$, with an $\mathrm{R}$-squared of 0.6218$]$. Spore's predicted volume (in $\mu \mathrm{m}^{3}$ ) is equal to $216.824+21.81 *$ mean temperature (in $\left.{ }^{\circ} \mathrm{C}\right)+$ $0.14 *$ mean precipitation (in $\mathrm{mm}$ ). No significant regression equation was found for $\mathrm{Q}$.

Average spore size increases with annual rainfall in $H$. aff. damaziana (Table 5), and leeward localities are, at similar elevations, generally drier than windward localities (see above). Therefore, it is to be expected that overall spore size will be smaller in the first ones, as highlighted in Figure 4. Taking separately into account samples collected in windward locations and those from leeward locations, the link between average spore volume and elevation is clearly strengthened in the case of specimens from the twenty-three windward localities (Fig. 4; $\mathrm{r}_{\mathrm{s}}=-0.8409, P=5.1 \times 10^{-7}$, two-tailed), but it is not significant for those from the nine leeward localities (Fig. $4 ; \mathrm{r}_{\mathrm{s}}=-0.3515, P>0.10$, two-tailed).

\section{Spore variation among localities in Hypotrachyna altorum}

The spores of $H$. altorum are smaller than those of $H$. aff. damaziana, as shown by the measurements from 14 specimens: length 8.5-8.92-9.4 $\mu \mathrm{m}$ (Student's t-test, $\mathrm{t}=22.443$, $\mathrm{df}=44, P=1.0 \times 10^{-25}$, two-tailed), width $6.2-6.56-$ $6.9 \mu \mathrm{m}$ (Student's t-test, $\mathrm{t}=19.287, \mathrm{df}=44, P=4.3 \times 10^{-23}$, two-tailed), volume 175.1-203.48-231.9 $\mu^{3}$ (Welch's t-test, $\mathrm{t}=25.068, \mathrm{df}=42, P<0.0001$, two-tailed). Overall, they are also somewhat more globose (Q 1.29-1.371.44) (Student's t-test, $\mathrm{t}=4.342, \mathrm{df}=44, P=8.2 \times 10^{-5}$, two-tailed). One-way ANOVA of the data shows that 
Table 6. Results of two-tailed Spearman's rank correlation between H. altorum spore traits and selected environmental factors. Correlation coefficients in bold type are statistically significant at $P<0.05$ (significance levels adjusted with the sequential Bonferroni correction for tests involving climate parameters). $\mathrm{CV}$ : coefficient of variation.

\begin{tabular}{|c|c|c|c|c|}
\hline & Elevation & $\begin{array}{c}\text { Mean annual } \\
\text { temperature }\end{array}$ & $\begin{array}{l}\text { Mean annual } \\
\text { precipitation }\end{array}$ & $\begin{array}{l}\text { Annual mean daily } \\
\text { global solar radiation }\end{array}$ \\
\hline Mean width & $\begin{array}{c}\mathbf{r}_{\mathbf{s}}=-\mathbf{0 . 6 0 5 7} \\
P=0.022\end{array}$ & $\begin{array}{c}\mathrm{r}_{\mathrm{s}}=0.0933 \\
P=0.75\end{array}$ & $\begin{array}{c}\mathrm{r}_{\mathrm{s}}=0.3831 \\
P=0.18\end{array}$ & $\begin{array}{c}\mathrm{r}_{\mathrm{s}}=0.2508 \\
P=0.39\end{array}$ \\
\hline $\mathrm{CV}$ of width & $\begin{array}{c}\mathrm{r}_{\mathrm{s}}=0.0792 \\
P=0.78\end{array}$ & $\begin{array}{c}\mathrm{r}_{\mathrm{s}}=0.3368 \\
P=0.24\end{array}$ & $\begin{array}{c}\mathrm{r}_{\mathrm{s}}=-0.1157 \\
P=0.69\end{array}$ & $\begin{array}{c}\mathrm{r}_{\mathrm{s}}=-0.0820 \\
P=0.78\end{array}$ \\
\hline Mean length & $\begin{array}{c}\mathrm{r}_{\mathrm{s}}=-0.2970 \\
P=0.30\end{array}$ & $\begin{array}{c}\mathrm{r}_{\mathrm{s}}=0.0921 \\
P=0.75\end{array}$ & $\begin{array}{c}\mathrm{r}_{\mathrm{s}}=0.2247 \\
P=0.44\end{array}$ & $\begin{array}{c}\mathrm{r}_{\mathrm{s}}=0.4590 \\
P=0.099\end{array}$ \\
\hline $\mathrm{CV}$ of length & $\begin{array}{c}\mathrm{r}_{\mathrm{s}}=0.0220 \\
P=0.94\end{array}$ & $\begin{array}{c}\mathrm{r}_{\mathrm{s}}=0.1617 \\
P=0.58\end{array}$ & $\begin{array}{c}\mathrm{r}_{\mathrm{s}}=-0.0623 \\
P=0.83\end{array}$ & $\begin{array}{c}\mathrm{r}_{\mathrm{s}}=0.0022 \\
P=0.99\end{array}$ \\
\hline Mean volume & $\begin{array}{c}\mathbf{r}_{\mathbf{s}}=-\mathbf{0 . 6 6 0 1} \\
P=0.010\end{array}$ & $\begin{array}{c}\mathrm{r}_{\mathrm{s}}=0.3098 \\
P=0.28\end{array}$ & $\begin{array}{c}\mathrm{r}_{\mathrm{s}}=0.3271 \\
P=0.25\end{array}$ & $\begin{array}{c}\mathrm{r}_{\mathrm{s}}=0.3127 \\
P=0.28\end{array}$ \\
\hline $\mathrm{CV}$ of volume & $\begin{array}{c}\mathrm{r}_{\mathrm{s}}=-0.0990 \\
P=0.74\end{array}$ & $\begin{array}{c}\mathrm{r}_{\mathrm{s}}=0.3009 \\
P=0.30\end{array}$ & $\begin{array}{c}\mathrm{r}_{\mathrm{s}}=-0.1201 \\
P=0.68\end{array}$ & $\begin{array}{c}\mathrm{r}_{\mathrm{s}}=-0.1973 \\
P=0.50\end{array}$ \\
\hline Mean Q & $\begin{array}{c}\mathrm{r}_{\mathrm{s}}=0.1496 \\
P=0.61\end{array}$ & $\begin{array}{c}\mathrm{r}_{\mathrm{s}}=0.0135 \\
P=0.96\end{array}$ & $\begin{array}{c}\mathrm{r}_{\mathrm{s}}=-0.3293 \\
P=0.25\end{array}$ & $\begin{array}{c}\mathrm{r}_{\mathrm{s}}=0.0599 \\
P=0.84\end{array}$ \\
\hline $\mathrm{CV}$ of $\mathrm{Q}$ & $\begin{array}{c}\mathrm{r}_{\mathrm{s}}=0.2178 \\
P=0.45\end{array}$ & $\begin{array}{c}\mathrm{r}_{\mathrm{s}}=0.1190 \\
P=0.69\end{array}$ & $\begin{array}{c}\mathrm{r}_{\mathrm{s}}=0.0400 \\
P=0.89\end{array}$ & $\begin{array}{c}\mathrm{r}_{\mathrm{s}}=0.2240 \\
P=0.44\end{array}$ \\
\hline
\end{tabular}

there is a very significant difference across mean length $\left(\mathrm{F}_{13,406}=12.072, P=2.7 \times 10^{-22}\right)$, width $\left(\mathrm{F}_{13,406}=17.253\right.$, $\left.P=1.1 \times 10^{-31}\right)$, volume $\left(\mathrm{F}_{13,406}=19.428, P=2.3 \times 10^{-35}\right)$ and $\mathrm{Q}\left(\mathrm{F}_{13,406}=8.943, P=3.3 \times 10^{-16}\right)$ among the 14 samples. The Hartigans' dip test shows, however, that there is no reason to consider the study population as heterogeneous, either for length $(P=0.99)$, width $(P=0.98)$, volume $(P=0.61)$ or $\mathrm{Q}$ values $(P=0.82)$. Intrathalline variation of spore size or shape parameters is fairly comparable to that of $H$. aff. damaziana (Table 4). However, the mean $\mathrm{CV}$ values of the samples differ significantly between the two species for length (Student's $\mathrm{t}$-test, $\mathrm{t}=3.428$, $\mathrm{df}=44, P=0.0013$, two-tailed $)$, width $(\mathrm{t}=2.930, \mathrm{df}=44$, $P=0.0054$, two-tailed) and volume $(\mathrm{t}=2.319, \mathrm{df}=44$, $P=0.025$, two-tailed). Interthalline variation, on the other hand, is remarkably similar between the two species. As for $H$. aff. damaziana, the comparison between intra- and interthalline variation shows that the former is higher than the latter (Table 4).

Despite the relatively narrow elevational range of H. altorum (1485-1850 m), the mean width and volume values are significantly correlated with the elevation of the surveyed localities. Both decrease as elevation increases (Table 6, Fig. 3). In H. altorum, as in H. aff. damaziana, the shape of spores does not appear to change with elevation (Table 6). For volume and width, a regression model with elevation as the only explanatory variable was selected. Significant regression equations were found $\left[\mathrm{F}_{1,12}=8.442, P=0.0132\right.$, with an R-squared of 0.3641 for volume and $F_{1,12}=7.387, P=0.0187$, with an $R$-squared of 0.3295 for width, respectively]. Spore's predicted volume (in $\mu \mathrm{m}^{3}$ ) is equal to $461.193-0.153 *$ elevation (in $\mathrm{m}$ ) and spore's predicted width is equal to $9.708-0.00187$ * elevation (in $\mathrm{m}$ ), respectively. No significant regression equation was found for length and Q.

For $H$. altorum, no significant relation between the biometric parameters and the three selected climatic variables was found (Table 6).

\section{Discussion}

\section{Intraspecific variation}

The two species investigated belong to the same genus but are not closely related. According to a preliminary molecular phylogenetic analysis (Masson \& Sérusiaux unpubl. data), including 14 of the 46 samples studied here ( 10 of $H$. aff. damaziana and 4 of $H$. altorum, cf. Table $1 \&$ Fig. 3), $H$. aff. damaziana belongs to subgenus Parmelinopsis and H. altorum to subgenus Hypotrachyna (as defined by Divakar et al. 2013), subgenera that split off during the Oligocene according to Cubas et al. (2018). This phylogenetic analysis also shows that the 10 specimens attributed to $H$. aff. damaziana on morphological and chemical criteria are genetically very similar according to their ITS rDNA gene sequences, as are the 4 specimens attributed to $H$. altorum. This is in agreement with the 'normal' interthalline variability of the spore parameters of the two Hypotrachyna species (see comments on the evaluation of spore variability in Parmasto \& Parmasto 1987) and with the results of the Hartigans' dip test suggesting unimodality in interthalline variability of spore features in the two taxa. All these data are consistent with the hypothesis that each of the two species represents a homogeneous population. Therefore, the interthalline variation in spore size highlighted in this work is assumed to represent only intraspecific variation within the two species. Variation due to the additional presence of one or more cryptic taxa is unlikely.

Intraspecific variation in ascospore size and shape has rarely been studied in detail in lichens, and we are not aware of any comprehensive and synthetic work on this subject comparable to that of Parmasto \& Parmasto (1987) on basidiospores in the hymenomycetes. Intra-individual variation, in particular, is seldom investigated. In a pioneering work, Löfgren \& Tibell (1979) studied the variation in mean length and width of ascospores between ten apothecia from a specimen of Sphinctrina 
anglica. No coefficient of variation was calculated in that work, but according to their figure 3 it is possible to estimate variation in mean spore size between apothecia of $\sim 3-4 \%$. The values obtained with $H$. aff. damaziana, following a similar protocol, are quite comparable although somewhat lower: the four coefficients of variation calculated from the means of size and shape parameters range between $1.1 \%$ and $2.2 \%$. No significant differences in mean spore size or shape were observed between the ten apothecia of the same $H$. aff. damaziana specimen. Parmasto \& Parmasto (1987) came to the same conclusion in a comparison of basidiospores from different pilei having a common stem in one Collybia and two Pleurotus species. It has been shown in Basidiomycota that the size of spores may depend on the size of the basidioma that produces them (e.g., Hanna 1926; Parmasto \& Parmasto 1987). Depending on the species, the correlation between spore size and diameter of the pileus can be positive or negative (Clémençon 1979). The same is true for the two lichenized Ascomycota studied: a positive significant correlation between the diameter of the hymenial disc and mean spore width and volume in $H$. aff. damaziana, and a negative one between disc diameter and mean spore length and volume in H. altorum. However, when performing multiple linear regressions with elevation, climatic parameters and diameter of the apothecia as explanatory variables, the diameter of the apothecia was only selected as a significant explanatory variable for the width of spores in $H$. aff. damaziana. On the other hand, models with only elevation or climatic variables were selected to predict spore length and volume in $H$. aff. damaziana, and spore volume and width in H. altorum.

The variation of size and shape between spores within an apothecium is much greater than the variation in mean spore size and shape between apothecia of the same thallus, and thus constitutes the essential component of intrathalline variation. The variability of the size and shape of spores produced by one individual is not negligible. Thus, the smallest and the largest spores, within the $90 \%$ tolerance limits of intrathalline variation, have a volume ratio of 1/1.6-2.7 in $H$. aff. damaziana and 1/1.5-2.5 in $H$. altorum. The size variability of spores produced by the same thallus could be caused by 'competition' between developing spores within the limited volume of each ascus. However, similar values of intrathalline variation were obtained by Parmasto \& Parmasto (1987) from basidiospores, whereas the development of these is much less constrained by the available space (Halbwachs \& Bässler 2015). These authors have proposed to consider this intra-individual variation as a compromise, controlled by natural selection, meeting the need for local as well as long-distance dispersal. Small wind-borne spores are dispersed over greater distances than large spores are (Norros et al. 2014).

\section{Influence of elevation and climatic factors}

As expected, mean spore size varies with elevation. In both species studied, mean length, width and volume decrease as elevation increases, with particularly significant variation for spore width and spore volume. Unlike size, the shape of spores (expressed by the Q value) does not vary significantly with elevation for the two species investigated. It is interesting to note that the intrathalline variability of the three spore size parameters of $H$. aff. damaziana also changes with elevation. The $\mathrm{CV}$ of width and volume decreases, while the $\mathrm{CV}$ of length increases with elevation.

Variation in mean spore volume between $H$. aff. damaziana specimens could be correlated with two climatic variables: mean annual rainfall and, especially, mean annual temperature of the sampling localities. Mean volume is greater in places with higher average temperature or higher rainfall. In this species, the change in temperature leads not only to a substantial change in mean spore size between specimens, but also to a significant change in intrathalline variability. No significant correlation between climatic variables and the mean spore size of $H$. altorum was found, although size decreased with elevation. It is likely that the low resolution of the available climatic data, the small number of localities investigated, and their heterogeneity with regard to their exposure to trade winds (6 windward vs. 8 leeward localities) are responsible for the lack of correlation in this species. Laboratory and outdoor cultures of various species of non-lichenized fungi have shown that the size of their spores varied significantly under the effect of various environmental factors such as temperature, humidity, light, pH, etc. (e.g., Williams 1959; Dingley 1962; Petrie 1994). These studies also make it clear that responses vary among taxa. For example, the length of spores decreases when the temperature rises from $15^{\circ} \mathrm{C}$ to $25^{\circ} \mathrm{C}$ in Mucor dispersus but increases in Sordaria fimicola (Williams 1959). The underlying mechanisms leading to these differences in variation are unfortunately not identified. The growth of a single cell such as an ascospore of Hypotrachyna is not directly comparable to that of the whole thallus of a lichen, but in both cases the influence of temperature seems to have the same effect. Depending in particular on their respective elevations, the thirty-two localities where specimens of $H$. aff. damaziana were collected have annual mean temperature varying from $11^{\circ} \mathrm{C}$ to $21.5^{\circ} \mathrm{C}$. It has been shown that within this temperature range the growth of numerous lichen mycobionts in isolated culture increases with temperature (Thomas 1939; Henriksson 1964). Net photosynthesis, on the other hand, increases from $10^{\circ} \mathrm{C}$ to $\sim 20^{\circ} \mathrm{C}$ in several tropical epiphytic foliose lichens (Zotz et al. 1998, 2003; Lange et al. 2004), whereas mean radial growth, measured in the field, shows a significant positive linear correlation with mean air temperature (range: $\sim-5^{\circ} \mathrm{C}$ to $+15^{\circ} \mathrm{C}$ ) in two parmelioid lichen species of the genus Xanthoparmelia (Benedict 1990).

\section{Taxonomic observations}

The variability in the size and shape of mature spores produced by an individual, as well as the variability among individuals of the same species, are due to environmental and genetic factors. The present study suggests an influence of elevation on spore size in two species of lichenized fungi. This influence would be exerted at both intra- and inter-individual levels in $H$. aff. damaziana 
Table 7. Ascospore dimensions of taxa of the H. damaziana complex according to different authors.

\begin{tabular}{|c|c|c|c|c|c|}
\hline Origin of material & Réunion & Kenya & \multicolumn{3}{|c|}{ Brazil } \\
\hline Spore size $(\mu \mathrm{m})$ & $12.8-14.2 \times 8.8-9.7$ & $16-18 \times 10-12$ & $12-18 \times 8-12$ & $(13) 16-18 \times(6.5) 8-12$ & $(10) 12-14 \times 6.5-9$ \\
\hline Total number of samples studied & 32 & 1 & - & - & - \\
\hline Total number of spores studied & 960 & - & - & - & - \\
\hline Source & present study & Krog \& Swinscow 1979 & Hale 1976 & Eliasaro \& Adler 2000 & Jungbluth 2007 \\
\hline
\end{tabular}

and at least at the inter-individual level in $H$. altorum. It is noteworthy that the interthalline variation, that is, the variation in mean spore dimensions or shape index $(\mathrm{Q})$ between specimens of one species, remains relatively low despite the wide elevational range of $H$. aff. damaziana (from $620 \mathrm{~m}$ to $2375 \mathrm{~m}$ a.s.1.). This inter-individual variability is also remarkably similar between the two species $H$. altorum and $H$. aff. damaziana for all four investigated variables. The coefficients of variation for length, width or shape are between $5.0 \%$ and $5.7 \%$ for the two Hypotrachyna species. These results are slightly lower than the average values obtained by Parmasto \& Parmasto (1987) from basidiospores for the same parameters (length: 6.5\%, width: $6.3 \%$, Q: $6.1 \%$ ). In three parmelioid lichens of the genus Parmelina, interthalline variation, estimated with coefficients of variation values, ranged from $2.8 \%$ to $6.4 \%$ for length, $3.9 \%$ to $7.4 \%$ for width, and $3.4 \%$ to $10.2 \%$ for Q (our own calculations, adapted from Argüello et al. 2007 - Table 2).

Measurements of spores constitute an essential part of descriptions of fungi, whether lichenized or not (Hawksworth 1974). The general usage is to present the range of the 'normal' variation of spore measurements, often with the extremes recorded in parentheses. Most often, unfortunately, the values presented combine both intra- and inter-individual variability. The variation of spores between individuals of a species is a character of that species, and not the variation within one individual, which is a character of that particular individual. In addition, intra-individual variability in spore size and shape is not an adequate indicator of inter-individual variability (see Parmasto \& Parmasto 1987 for a detailed discussion). The generally applied combination of intra- and inter-individual variation leads to a wider range of variability than that obtained only from the individual mean values of spore measurements, and it introduces considerable background noise (Raitviir 1972). The current lack of standardization in establishing ranges of variation in spore measurements usually prevents any relevant comparison between the data published by different authors. This is the case, for example, for the taxa in the H. damaziana complex (Table 7).

\section{Acknowledgements}

We warmly thank Paul Diederich (Luxembourg), Claude Roux (Mirabeau) and the anonymous reviewers for helpful suggestions and constructive comments on various versions of the manuscript. Fieldwork of the first author in Réunion National Park was carried out under permits DIR/I/2012/034, DIR/I/2013/046, DIR/I/2015/102 and DIR/I/2017/100. It is a great pleasure to dedicate this contribution to Emmanuël Sérusiaux for his assistance and encouragement in the study of parmelioid lichens in Réunion by the first author.

\section{References}

Argüello, A., Del Prado, R., Cubas, P. \& Crespo, A. 2007. Parmelina quercina (Parmeliaceae, Lecanorales) includes four phylogenetically supported morphospecies. Biological Journal of the Linnean Society 91: 455-467.

Benedict, J. B. 1990. Experiments on lichen growth. I. Seasonal patterns and environmental controls. Arctic and Alpine Research 22: 244-254.

Clémençon, H. 1979. Biometrische Untersuchungen zur Variabilität der Basidiosporen. Beihefte zur Sydowia 8: 110-138.

Clerc, P. 1984. Contribution à la révision systématique des Usnées (Ascomycotina, Usnea) d'Europe I. Usnea florida (L.) Wigg. emend. Clerc. Cryptogamie, Bryologie et Lichénologie 5: 333-360.

Cubas, P., Lumbsch, H. T., Del Prado, R., Ferencova, Z., Hladun, N. L., Rico, V. J. \& Divakar, P. K. 2018. Historical biogeography of the lichenized fungal genus Hypotrachyna (Parmeliaceae, Ascomycota): insights into the evolutionary history of a pantropical clade. The Lichenologist 50: 283-298.

Dingley, J. M. 1962. Pithomyces chartarum, its occurrence, morphology, and taxonomy. New Zealand Journal of agricultural Research 5: 49-61.

Divakar, P. K., Crespo, A, Núñez-Zapata, J., Flakus, A., Sipman, H. J. M., Elix, J. A. \& Lumbsch, H. T. 2013. A molecular perspective on generic concepts in the Hypotrachyna clade (Parmeliaceae, Ascomycota). Phytotaxa 132: 21-38.

Doré, C. J., Cole, M. S. \& Hawksworth, D. L. 2006. Preliminary statistical studies of the infraspecific variation in the ascospores of Nesolechia oxyspora growing on different genera of parmelioid lichens. The Lichenologist 38: 425-434.

Eliasaro, S. \& Adler, M. T. 2000. The species of Canomaculina, Myelochroa, Parmelinella, and Parmelinopsis (Parmeliaceae, lichenized Ascomycotina) from the 'Segundo Planalto' in the state of Paraná, Brazil. Acta Botanica Brasilica 14: 141-149.

Flakus, A., Etayo, J., Schiefelbein, U. L. F., Ahti, T., Jablónska, A., Oset, M., Bach, K., Flakus, P. R. \& Kukwa, M. 2012. Contribution to the knowledge of the lichen biota of Bolivia. 4. Polish Botanical Journal 57: 427-461.

Fox, J., Weisberg, S., Adler, D., Bates, D. et al. 2012. Package 'car'. Vienna: R Foundation for Statistical Computing.

Gauslaa, Y. 2014. Rain, dew, and humid air as drivers of morphology, function and spatial distribution in epiphytic lichens. The Lichenologist 46: 1-16.

Halbwachs, H. \& Bässler, C. 2015. Gone with the wind - a review on basidiospores of lamellate agarics. Mycosphere 6: 78-112.

Haldane, J. B. S. 1955. The measurement of variation. Evolution 9: 484.

Hale, M. E. 1976. A monograph of the lichen genus Parmelina Hale (Parmeliaceae). Smithsonian Contributions to Botany 33: 1-60.

Hanna, W. F. 1926. The inheritance of spore size in Coprinus sterquilinus. Transactions of the British Mycological Society 11: 219-238.

Hawksworth, D. L. 1973. Ecological factors and species delimitation in the lichens. In: Heywood, V. H. (ed.), Taxonomy and Ecology, pp. 31-69. Academic Press, London. 
Hawksworth, D. L. 1974. Mycologist's Handbook. An introduction to the principles of taxonomy and nomenclature in the fungi and lichens. Commonwealth Mycological Institute, Kew.

Henriksson, E. 1964. Studies in the physiology of the lichen Collema. V. Effect of medium, temperature, and $\mathrm{pH}$ on growth of the mycobiont. Svensk Botanisk Tidskrift 58: 361-370.

Holm, S. 1979. A simple sequentially rejective multiple test procedure. Scandinavian Journal of Statistics 6: 65-70.

Jumaux, G., Quetelard, H. \& Roy, D. 2011. Atlas climatique de La Réunion. Météo-France.

Jungbluth, P. 2006. A família Parmeliaceae (fungos liquenizados) em cerrados do Estado de São Paulo, Brasil. Dissertação (mestrado), Instituto de Botânica da Secretaria de Estado do Meio Ambiente, São Paulo.

Kassambara, A. 2017. ggpubr: 'ggplot2' based publication ready plots. $\mathrm{R}$ package version 0.1 .6 .

Kershaw, K. A. 1985. Physiological ecology of lichens. Cambridge University Press, Cambridge.

Kirika, P. M., Divakar, P. K., Crespo, A. \& Lumbsch, H. T. 2019. Molecular and phenotypical studies on species diversity of Hypotrachyna (Parmeliaceae, Ascomycota) in Kenya, East Africa. The Bryologist 122: $140-150$.

Körner, C. 2007. The use of 'altitude' in ecological research. Trends in Ecology \& Evolution 22: 569-574.

Krog, H. \& Swinscow, T. D. V. 1979. Parmelia subgenus Hypotrachyna in East Africa. Norwegian Journal of Botany 26: 11-43.

Lange, O. L., Büdel, B., Meyer, A., Zellner, H. \& Zotz, G. 2004. Lichen carbon gain under tropical conditions: water relations and $\mathrm{CO}_{2}$ exchange of Lobariaceae species of a lower montane rainforest in Panama. The Lichenologist 36: 329-342.

Le Roux, J. J., Strasberg, D., Rouget, M., Morden, C. W., Koordom, M. \& Richardson, D. M. 2014. Relatedness defies biogeography: the tale of two island endemics (Acacia heterophylla and A. koa). New Phytologist 204: 230-242.

Löfgren, O. \& Tibell, L. 1979. Sphinctrina in Europe. The Lichenologist 11: 109-137.

Martínez, I. \& Burgaz, A. R. 1998. Revision of the genus Solorina (Lichenes) in Europe based on spore size variation. Annales Botanici Fennici 35: 137-142.

Masson, D. 2012. Hypotrachyna altorum sp. nov., a new lichen from the cloud forests of Réunion Island, Indian Ocean. Cryptogamie, Mycologie 33: 203-212.

Nash III, T. H., Pérez-Pérez, R. E. \& Elix, J. A. 2016. Hypotrachyna in Mexico. Bibliotheca Lichenologica 110: 155-256.

Norros, V., Rannik, U., Hussein, T., Petäjä, T., Vesala, T. \& Ovaskainen, O. 2014. Do small spores disperse further than large spores? Ecology 95: 1612-1621.

Núñez-Zapata, J., Divakar, P. K., Del-Prado, R., Cubas, P., Hawksworth, D. L. \& Crespo, A. 2011. Conundrums in species concepts: the discovery of a new cryptic species segregated from Parmelina tiliacea (Ascomycota: Parmeliaceae). The Lichenologist 43: 603-616.

Palmqvist, K., Dahlman, L., Jonsson, A. \& Nash III, T. H. 2008. The carbon economy of lichens. In: Nash III, T. H. (ed.), Lichen Biology. Ed. 2, pp. 182-215. Cambridge University Press, New York.
Parmasto, E. \& Parmasto, I. 1987. Variation of basidiospores in the Hymenomycetes and its significance to their taxonomy. Bibliotheca Mycologica 115: 1-168.

Pena, E. A. \& Slate, E. H. 2012. gvlma: Global validation of linear models assumptions. R package version 1.0. 0.1.

Pentecost, A. 1981. Some observations on the size and shape of lichen ascospores in relation to ecology and taxonomy. New Phytologist 89: $667-678$.

Petrie, G. A. 1994. Effects of temperature and moisture on the number, size and septation of ascospores produced by Leptosphaeria maculans (blackleg) on rapeseed stubble. Canadian Plant Disease Survey 74: 141-151.

Poelt, J. 1973. Systematic evaluation of morphological characters. In: Ahmadjian, V. \& Hale, M. E. (ed.), The lichens, pp. 91-115. Academic Press, New York and London.

R Core Team 2018. R: A language and environment for statistical computing. R Foundation for statistical computing, Vienna.

Raitviir, A. 1972. Statistical methods and species delimitation in the genus Otidea. Persoonia 6: 415-423.

Rice, W. R. 1989. Analyzing tables of statistical tests. Evolution 43: 223-225.

Strasberg, D., Rouget, M., Richardson, D. M., Baret, S., Dupont, J. \& Cowling, R. M. 2005. An assessment of habitat diversity and transformation on La Réunion Island (Mascarene Islands, Indian Ocean) as a basis for identifying broad-scale conservation priorities. Biodiversity and Conservation 14: 3015-3032.

Thomas, E. A. 1939. Über die Biologie von Flechtenbildnern. Beiträge zur Kryptogamenflora der Schweiz 9: 1-205.

Truong, C., Naciri, Y. \& Clerc, P. 2009. Multivariate analysis of anatomical characters confirms the differentiation of two morphologically close species, Melanohalea olivacea (L.) O. Blanco et al. and M. septentrionalis (Lynge) $\mathrm{O}$. Blanco et al. The Lichenologist 41: 649-661.

Van den Boom, P. P. G., Brand, M., Ertz, D., Kalb, K., Magain, N., Masson, D., Schiefelbein, U., Sipman, H. J. M. \& Sérusiaux, E. 2011. Discovering the lichen diversity of a remote island: working list of species collected on Reunion (Mascarene archipelago, Indian Ocean). Herzogia 24: 325-349.

Van Herk, C. M., Aptroot, A. \& van Dobben, H. F. 2002. Long-term monitoring in the Netherlands suggests that lichens respond to global warming. The Lichenologist 34: 141-154.

Weber, W. A. 1977. Environmental modification and lichen taxonomy. In: Seaward, M. R. D. (ed.), Lichen Ecology, pp. 9-29. Academic Press, London.

Wickham, H. 2012. reshape2: Flexibly reshape data: a reboot of the reshape package. $\mathrm{R}$ package version 1.2

Wickham, H., François, R., Henry, L. \& Müller, K. 2016. dplyr: A grammar of data manipulation. $\mathrm{R}$ package version 0.5 .

Williams, C. N. 1959. Spore size in relation to culture conditions. Transactions of the British Mycological Society 42: 213-222.

Zotz, G., Büdel, B., Meyer, A., Zellner, H. \& Lange, O. L. 1998. In situ studies of water relations and $\mathrm{CO}_{2}$ exchange of the tropical macrolichen, Sticta tomentosa. New Phytologist 139: 525-535.

Zotz, G., Schultz, S. \& Rottenberger, S. 2003. Are tropical lowlands a marginal habitat for macrolichens? Evidence from a field study with Parmotrema endosulphureum in Panama. Flora 198: 71-77. 